\title{
THE QUIET EVOLUTION
}




\title{
THE QUIET EVOLUTION
}

The Planning, Development, Management and Provision of Community Services for the Mentally Handicapped

\author{
Edited by \\ DAVID LANE \\ SHEILA NOBLE \\ MICHAEL TIDBALL \\ SAM TWIGG
}


Text (C) the contributors 1983

Photographs (C) Raissa Page 1983

All rights reserved. No part of this publication may be reproduced or transmitted, in any form or by any means, without permission.

First published 1983 by

THE MACMILLAN PRESS LTD

London and Basingstoke

Companies and representatives throughout the world

ISBN 978-0-333-35175-8

ISBN 978-1-349-17078-4 (eBook)

DOI 10.1007/978-1-349-17078-4 


\section{Contents}

The Contributors vii

Foreword Brian Rix xiv

Acknowledgements $\quad \mathrm{xv}$

1. Something to Shout about? David Lane 1

2. Getting the Show on the Road Michael Tidball 4 -Planning the Development of Services

3. Where the Cash Comes from

4. Keeping the Show Going - the Management of Day and Residential Establishments in the Social Services

5. Who Says Small is Beautiful? -in Defence of the Large Hostel

6. Hobart and Goleudy -Group Home Living

7. All in a Day's Work

Michael Tidball 37 and Sheila Noble

David Lane and 50 Sam Twigg

Sue Gostick

65

8. Merrimans

Ciaran Beary

75

John Spargo

9. Community Services

Joy Wake 123

David Donaldson 130

10. Education Policy and Practice

11. Planning the Health Services

Ruth Heywood and 140 Chris Waterman

David Blythe 161

12. The Superpsyche Roadshow -the Clinical Psychologist and

Roger Ramsden the Community

13. The Psychiatrist's Viewpoint

Charles Finn

14. The Community Nurse's Role

Tony Moore 
vi Contents

15. Holy Child House

16. How Parents See it

17. Restoration of Citizenship

18. Conclusions

Bibliography

Appendix A: Development of

Establishments for Mentally

Handicapped People in Hillingdon
Betty Froud and Michael Tidball

Nelson and Shirley Court Ciaran Beary 251

David Lane

Appendix B: The Keyworker Scheme

David Lane

Appendix C: Useful Addresses

Index
260

266 269

270

272

223

273 


\section{The Contributors}

\section{Ciaran Beary}

Ciaran Beary has worked in Hillingdon for some three years now, first as an assistant officer-in-charge of a large hostel and at present as officer-in-charge of a small group home. He has lived with mentally handicapped people in a variety of settings ranging from a national health hospital to a Camp Hill Village Community as a student when he was actively involved in developing a student/mentally handicapped home in North Wales.

Ciaran holds a BA Social Administration (University College North Wales, Bangor), Diploma in Applied Social Studies and Certificate of Qualification in Social Work. He is also a member of the Residential Care Association.

\section{David Blythe}

After graduating from Cambridge in 1961 David Blythe started his NHS career with the Leeds Regional Hospital Board, moving first to the Liverpool and South East Metropolitan R.H.B. and from there to the Royal Marsden Hospital Board. He joined Hillingdon Area Health Authority in 1974, initially as general administrator concerned with service development and from 1979 as Area Administrator. He is now District Administrator following NHS reorganisation. David Blythe has always had a keen interest in planning and is Chairman of the Joint Care Planning Team for the Mentally Handicapped in Hillingdon. He is married with four children and is a magistrate.

Shirley and Nelson Court

Shirley and Nelson Court are parents of two boys. One is at University and the other is a sixteen year old Mongol-the two 


\section{viii The Contributors}

extremes of the intelligence spectrum allow for some interesting comparisons not always favourable to the more intelligent! Having been inveigled into representing the local Mencap Societies on the CHC seven years ago, Shirley has now achieved the dizzy heights of Chairman of that body (quite how and why is a mystery to her!) and is now Chairman for a second term. As Mencap representative she sits on a number of committees and working groups. She is also associated with a parent support group. Nelson has less claim to fame. He has been a member of the Committee of the Hillingdon North Society for Mentally Handicapped Children \& Adults for about ten years. More importantly he drives the Society minibus! He admits to being an economist (unreconstructed Keynesian) by training which explains some of the extraneous comments.

Prior to starting work on this project Shirley spent much time in sometimes acrimonious confrontation with Mike Tidball (q.v.) and various politicians, egged on by her husband. Since then they have taken to spending their time in even more acrimonious confrontations with each other. Since agreement among themselves was difficult enough they would not claim to be representative of all parents of the mentally handicapped or Mencap, but have no reason to believe their views to be outrageously idiosyncratic.

Shirley is currently an observer on the Joint Care Planning Team for the mentally handicapped and is involved in the current search for suitable sites for hospital villas.

\section{David Donaldson}

After working for 10 years in industry and banking David Donaldson started his career in social work by studying full time for a London University External Diploma in Social Studies at Chiswick Polytechnic. On completing the course in 1967 he worked as an unqualified social worker in Ealing Welfare Department for three years before going on a qualification course at the L.S.E.

After qualifying he returned to the new Ealing Social Services Department for a year before becoming a Senior Social Worker in Brent in 1972. He has now been at Hillingdon since 1973, first as an Assistant Area Manager in Hayes and then as an Area Manager in West Drayton since 1979. 


\section{Charles Finn}

Charles Finn qualified at University College Hospital in 1954 and, whilst a house surgeon and house physician in 1954-55, became actively interested in the local psychiatric problems. Between 1955 and 1960 he trained in general psychiatry at Bexley Hospital. Charles decided to complete his psychiatric training by obtaining a short period of experience in mental handicap and moved to Leavesden Hospital, Hertfordshire in 1960.

He also served as visiting psychiatrist to the three small subnormality hospitals in the Windsor Group, leaving these at the time of the health service reorganisation in 1974. Since 1974 he has been responsible for Leavesden's mental handicap services to Hillingdon.

\section{Betty Froud}

After completing her nurse training, Betty Froud worked as a midwife for 2 years in New Zealand, which involved providing patient care for a Maori community. On her return to England she obtained her Certificate in Occupational Health and worked for a time in industry.

Betty Froud has been associated for many years with Harefield and Mount Vernon Hospitals and since 1974 has been Area Nurse (Service and Capital Planning) with the Hillingdon Health Authority. For the last year she has also been acting Divisional Nursing Officer for Mount Vernon and Harefield Hospitals.

\section{Sue Gostick}

Sue Gostick is the officer-in-charge of Charles Curran House, a new 24-bedded purpose-built hostel designed by Hillingdon's Building Design and Construction Department after discussion with parents and residential workers, with a unit specifically for the profoundly handicapped.

Before working in Hillingdon she was a housemother in two approved schools and has also worked in old peoples' homes and a holiday home for physically handicapped people.

Since obtaining her C.R.S.W. at Chiswick Polytechnic she has helped to open two new hostels in Hillingdon, Hatton Grove and Charles Curran House. She is also a member of the Residential 


\section{x The Contributors}

Care Association and has been Chairman of the Hillingdon Branch.

\section{Ruth Heywood}

From a happy childhood on a busy farm in Buckinghamshire, Ruth Heywood left secondary school to attend art college with aspirations towards portraiture and a Parisian garret! Reality was unkind-the only option seemed to be embellishing tea-cups in the Midlands.

After a variety of transitory modes of employment, from delivery driver to nursing auxiliary to a member of the building trade, quite by chance Ruth found herself employed as an unqualified teacher in a Junior Training Centre. In the last fifteen years she has trained, qualified, obtained further qualifications and taught in a number of inner and outer London schools.

Five years ago Ruth became head teacher at Moorcroft School and has become further and further involved in the education, in its widest sense, of mentally handicapped children. She finds it to be a demanding, challenging and rewarding way of life, in which she constantly wishes she could learn and achieve more.

\section{David Lane}

David Lane started his career in residential child care. As Social Work Education Adviser, at CCETSW, he was involved in the planning of training for residential staff, and in particular the development of the Certificate in Social Service. He has been a member of the Residential Care Association for many years and is currently President. Within the Association he has been involved in a range of professional practice matters, has edited several books and assisted in the preparation of reports on stress in residential work and staffing ratios. Since 1975 he has worked in Hillingdon and is Assistant Director responsible for day and residential services.

\section{Tony Moore}

Presently employed at Leavesden Hospital as Senior Nursing Officer Community Nursing which caters for five Health Districts within the North West Thames Region, Tony Moore did his 
mentally handicapped training at the Royal Western Counties Hospitals in Devon and remained there for five years. He left in 1974 and since that time he has been continuously employed as a Community Nurse apart from a break to do his psychiatric training. Tony Moore has been previously employed to introduce and develop community nursing services (Mental Handicap) in Buckinghamshire, Leeds and Norfolk.

Sheila Noble

Sheila Noble is Research and Management Information Officer in Hillingdon's Social Services Department. Her first degree was in history, her second in social administration, and between the two she worked in consumer research. She thinks local authority services are worth at least as much of the consumer researcher's attention as soap powder and sausages, and regrets that this view is so unpopular nowadays. She has contributed bits of two chapters and edited, or attempted to edit, some others.

\section{Raissa Page}

Raissa Page is a freelance photo journalist. She has travelled extensively both in this country and in the Third World, taking photographs of social and economic life. Her work has been published in the national newspapers and in various journals and magazines.

Before working on The Quiet Evolution she made an extensive study of conditions in several long term hospitals for the mentally handicapped in collaboration with television producer Nigel Evans, working on the films 'The Silent Minority' and 'We're Outsiders Now'. Some of these photographs appeared in the Observer Magazine.

Although her documentary work is wide ranging, she says she has a particular concern to help improve the quality of life of people 'who just happen to be mentally handicapped. Working on The Quiet Evolution has been a heartening and positive contrast to the conditions I photographed in long term hospitals. I hope the photographs go some way to conveying the positive approach I found in Hillingdon'. 


\section{xii The Contributors}

\section{Roger Ramsden}

Roger Ramsden has worked in the field of mental handicap ever since he became a clinical psychologist in 1968 . He is committed to the notion of 'community-based psychology' for all client groups and has recently been successful in establishing a District Clinical Psychology service in S. W. Herts. Nevertheless he believes in the need for a continuing contribution from psychologists in the longer-stay hospitals and units particularly in respect of staff support. Applied psychology applies to staff as well as clients. He has acted as specialist adviser to Health Authorities and Social Services Departments on the development of clinical psychology services in most of the north west London boroughs.

\section{John Spargo}

John Spargo has been working in Adult Training Centres since 1971, initially at Chesham, Buckinghamshire from 1971 and then High Wycombe from 1974. In 1976 he came to Hillingdon as Assistant Manager and was appointed Manager in 1978. He is a holder of the Diploma for Teachers of Mentally Handicapped Adults, gained in 1973/4. John's previous work experience was in food research and precision engineering.

\section{Mike Tidball}

Mike Tidball worked in and with a variety of voluntary organisations on research and management problems before writing an M.Sc thesis on the organisational characteristics of national charities. He came to Hillingdon in 1971 as Assistant Director (Research). From 1972 to 1982 he was responsible for research, training, planning, finance and administration in Hillingdon, including the capital programme and the development of services. $\mathrm{He}$ is particularly interested in financial matters and in integrating the results of research exercises with financial reviews and the department's forward planning. He is now Deputy Director of Social Services with Buckinghamshire County Council.

\section{Sam Twigg}

John Michael Twigg, known to everyone as Sam, began working with mentally handicapped people in 1961 at the age of $15 \frac{1}{2}$ years, 
as a cadet nurse. He commenced his training for the register of nurses for the mentally handicapped and qualified in 1967. Beginning a career in the National Health Service he completed a post graduate course and became an SRN. His greatest interest remained the care of the mentally handicapped and he returned to Prudhoe Hospital, Northumberland to become a Nursing Officer. Wanting to care for the mentally handicapped in the community, Sam embarked on a career in social services, first as an officer-incharge of an adult hostel and currently as a Principal Officer (Day and Residential Services) in Hillingdon. He is also a member of the Residential Care Association and is Deputy Regional Officer for S. E. England.

Joy Wake

Joy Wake started working for Hillingdon Social Services in 1976 having spent the two previous years successfully completing the Preliminary Residential Care course. She started work as a Residential Social Worker in a home for mentally handicapped children and was seconded from there to undertake the Certificate in Social Service course, specialising in the field of mental handicap. Joy returned to the children's home as a Senior Residential Social Worker after successfully obtaining the Certificate in Social Service but then, like the majority of ex-students, soon got itchy feet and applied for a senior post in a brand new establishment caring for mentally handicapped adults. Having obtained the post she worked in this establishment for a year before going into semiretirement with her new baby son.

\section{Chris Waterman}

After a first degree in English and American literature in 1970, Chris Waterman obtained a post graduate certificate in Education with distinction in 1971 and a Master's degree in Education in 1978. He has been Teacher/Deputy Head of primary schools in Newbury and Tutor/Lecturer in English language, basic literature and basic numeracy for adults at a college of further education.

Since 1979 Chris has been Assistant Education Officer with Hillingdon, initially for secondary schools, then special education. In 1981 he was appointed Senior Assistant Education Officer (Schools). 


\section{Foreword}

I am happy to provide a short message for this new book which presents the views of professionals from all disciplines on their role of helping families living with a mentally handicapped member in the London Borough of Hillingdon.

Their daily contact with the problems and difficulties experienced has enabled them to describe in considerable detail how current practice can be improved.

The 'inside view', however, provided by Nelson and Shirley Court (parents of a mentally handicapped child), summarises their own view of what is available today and makes constructive suggestions for future planning.

The book reveals some differences of opinion among the many professionals involved and indicates clearly the need for modification in the present administrative structure to improve the delivery of services to individuals and to families.

It is a valuable addition to the literature and will be most useful in the future training of workers in all the many different professions involved in the field of mental handicap who will need the greatest possible degree of co-operation, to ensure that families carrying this burden receive the help they so desperately need.

Brian Rix

Secretary-General

Royal Society for Mentally Handicapped

Children and Adults 


\section{Acknowledgements}

Since collaboration is one of the themes of this book, it will be no surprise that we are indebted to an unusually large number of people in putting the volume together. In addition to the nineteen named contributors there is a small army of colleagues, friends and relatives who have given support in gathering material or offering comment. In particular, we would wish to mention Cyril Rundle, Stan Mellish, Roy Mills, Charlotte Douglass, Adrianne Jones, Barley Oliver, Graham Smyth, and Susan Hooper, without their support the individual contributions would inevitably have presented a narrower picture.

All the material was written specifically for this book, except for the piece on Holy Child House (chapter 15) which first appeared in the Health and Social Services Journal, and we are indebted to the Editor for permission to publish it.

As the chapters have progressed from one draft to the next, we have relied on a large number of people for help with the typing: our thanks are due to them all, but in particular to Sue Baggott of Hillingdon Community Health Council, to our secretaries, Vera Pettifer and Margaret Payne, and to Chris Donald and all the staff of our Civic Centre Automatic Typing Pool.

The book would not have got off the ground if we had not received financial support from a variety of sources. The Residential Care Association granted some initial funding to help with clerical costs and permit us to get under way. Hillingdon Community Health Council were most supportive in paying for the photography by way of the advance purchase of copies. Finally, the London Borough of Hillingdon and Hillingdon Area Health Authority made a valuable contribution to production costs to ensure that the volume could be made as widely available as possible. We are indebted to all these bodies for their support.

Perhaps the most important input has been people's time; we are grateful to everyone who has written, commented, consulted, encouraged, edited, photographed, lobbied, or negotiated to help 


\section{xvi Acknowledgements}

the book on its way. We hope people have enjoyed collaborating in its production, and that our combined efforts are of help and interest to others.

David Lane

Sheila Noble

Michael Tidball

Sam Twigg 